\section{Development, health, and international policy: the research and innovation dimension}

\author{
Desenvolvimento, saúde e política internacional: \\ a dimensão da pesquisa \& inovação
}

Desarrollo, salud y política internacional:

la dimensión de la investigación e innovación
Paulo Marchiori Buss 1

Claudia Chamas 2

Miriam Faid 2

Carlos Morel 2

\begin{abstract}
This text main objective is to discuss development and health from the perspective of the influence of global health governance, using as the tracer the dimension of research, development, and innovation policies in health, which relate to both important inputs for the health system, like drugs and medicines, vaccines, diagnostic reagents, and equipment, and innovative concepts and practices for the improvement of health systems and public health. The authors examine the two main macro-processes that influence development and health: the post-2015 Development Agenda and the process under way in the World Health Organization concerning research and development, intellectual property, and access to health inputs. The article concludes, first, that much remains to be done for the Agenda to truly represent a coherent and viable international political pact, and that the two macro-processes related to innovation in health need to be streamlined. But this requires democratization of participation by the main stakeholders - patients and the general population of the poorest countries - since this is the only way to overcome a "zero sum" result in the clash in the current debates among member State representatives.
\end{abstract}

Research; Sustainable Development; Innovation

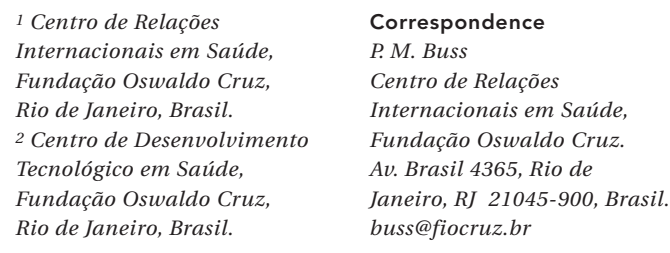

1 Centro de Relações Internacionais em Saúde, Fundação Oswaldo Cruz, Rio de Janeiro, Brasil. 2 Centro de Desenvolvimento Tecnológico em Saúde, Fundação Oswaldo Cruz, Rio de Janeiro, Brasil.

\author{
Correspondence \\ P. M. Buss \\ Centro de Relações \\ Internacionais em Saúde, \\ Fundação Oswaldo Cruz. \\ Av. Brasil 4365, Rio de \\ Janeiro, RJ 21045-900, Brasil. \\ buss@fiocruz.br
}




\section{Introduction}

Health and development are historically linked, whatever the meaning assigned to the two processes. When one assumes that both development and health are politically, economically, and socially produced, the links between these processes become even more evident.

There is reasonable consensus among various authors and institutions that work with health and development that health, defined as healthy populations and not merely the absence of diseases, is essential for economic and social development, and that when development is equitable, it contributes to the health of populations $1,2,3,4$ by allowing better living conditions and the implementation of systems and policies to protect the population.

Various political processes and economic crises that led to social disasters in the last 50-60 years and cyclical crises inherent to capitalist development, or structural ones, as the 2008 crisis appears to be, originating from the central countries in the capitalist system, produce harmful consequences for social systems and the population's health.

An example is the growing economic and social inequities in various countries and regions, which led the "international community", via the United Nations, to hold the Millennium Summit in 2000, following a series of World Conferences held by the various United Nations sector agencies (UNDP, UNICEF, FAO, and others) in the 1990s, aimed at preparing the world for the 21st century and disseminating the United Nations social agenda 5 . The Millennium Declaration and Millennium Development Goals (MDGs) 6 resulting from the Summit established commitments signed by the highest leaders of all the U.N. member States to back a set of well-defined goals ending in 2015.

New commitments are now being negotiated - the post-2015 Millennium Agenda and the Sustainable Development Goals (SDGs) - in a context of world economic crisis, politically oriented by the concept of sustainable development, a process with deep roots (Stockholm, 1972; Rio de Janeiro, 1992) reaffirmed by the United Nations Conference on Sustainable Development (Rio+20), and in September 2015 in the United Nations General Assembly (UNGA).

The policies and practices of technological innovation and its effects on public health are also structural. The development of medicines, vaccines, diagnostic resources, equipment, or innovations in health systems improvement responds to enormous economic interests, with repercussions on the population's health, as the various components unfold: production and appropriation of knowledge, technological development, production, and access. This is a field of political and economic disputes, with participation by producing countries (usually developed) and technologically dependent ones (usually developing, with rare exceptions), United Nations agencies, private corporations (mostly multinational), public institutes, and domestic and international foreign nongovernmental organizations, among other relevant stakeholders.

The article's main objective is to discuss development and health from the perspective of the influence of global health governance, using as a tracer the dimension of policies for health research, development, and innovation. These refer to important inputs for the health system, like drugs and medicines, vaccines, diagnostic reagents, and equipment, and also innovative concepts and practices for the improvement of health systems and public health.

\section{Global policies for development and health}

Health involves spaces for governance, articulation, decision-making, and powers generated and influenced by national-regional-global dynamics with increasingly imprecise boundaries. In other words, given the complex dynamics resulting from globalization, it is increasingly difficult to separate the national space from the global space, thus resulting in the need to consider different levels of governance to effectively draft and implement policies. This diffuse and challenging scenario has been shaken since 2007 by the most serious global financial crisis since the Great Depression of the late 1920s, stifling growth and revealing systemic weaknesses and persistent imbalances that require profound changes for the 21st-century world to develop inclusively.

"Global governance and health" is based on the recognition that health is heavily influenced by institutions and policies that are external to the health "sector" proper, like trade, intellectual property, work, and the environment, among others. Agreements like the Rio Political Declaration on Social Determinants of Health (2011) 7 and the Moscow Declaration of the First Global Ministerial Conference on Healthy Lifestyles and Non-communicable Disease Control (2011) 8 highlighted the multi-sector forces that influence health and wellbeing.

The Moscow Declaration emphasizes that "prevention and control of NCDs require (...) a wide range of multi-level, multi-sectoral measures, aimed at the full spectrum of NCD deter- 
minants (from individual-level to structural) to create the necessary conditions for leading a healthy life" 8.

Meanwhile the Rio Declaration assumes that "health equity is a shared responsibility and requires the engagement of all sectors of government, of all segments of society, and of all members of the international community, in an 'all for equity' and 'health for all' global action" 7. The same Declaration emphasizes that "health inequities within and between countries are politically, economically, and socially unacceptable - as well as unfair and largely avoidable" 7. The Declaration thus reaffirms the resolution by the World Health Assembly on Social Determinants of Health, highlighting three recommendations by the WHO Commission on Social Determinants of Health: improve living conditions; combat unequal distribution of power, money, and resources; and measure the magnitude of the problem, understand it, and assess the impact of interventions.

In another sphere, in 2007 the Oslo Ministerial Group, consisting of the Ministers of Foreign Affairs of seven countries (Brazil, France, Indonesia, Norway, Senegal, South Africa, and Thailand) issued the Oslo Ministerial Declaration on Global Health ${ }^{9}$, stating the need to assign priority to health in global political issues like trade, intellectual property rights, conflict and crisis management, development strategies, and foreign policy. In 2013, the Group pointed to the emergence of negative social, economic, and environmental determinants of health and called attention to the importance of monitoring non-health sector policies with health indicators, placing health at the center of the new universal framework for sustainable development 10 .

A comprehensive study by The Lancet-University of Oslo Commission 11 identified the "global political determinants of health", generators of inequities between and within countries and thus harmful to the health of populations and jeopardizing social protection and health systems. Such policies and practices include economic crises and austerity measures; intellectual property; treaties on foreign investment; food (in) security; transnational business activities; illegal immigration; and violent conflicts. The cases that were analyzed show that in the global governance panorama, power asymmetries between stakeholders with conflicting interests have a decisive influence on political determinants of health.

Meanwhile, the Group pf 77 (G77), in a report presented to the Open Working Group (OWG) on Sustainable Development Goals, reaffirms "the importance of taking advantage of the flexibilities afforded by the Agreement on Trade-Related
Aspects of Intellectual Property Rights (TRIPS Agreement) to promote people's health and access to medicines" 12 . In addition, the report exhorts the developed countries "to respect the developing countries' right to take full advantage of the flexibilities afforded by the TRIPS Agreement and to abstain from adopting measures, including of a commercial nature, that prevent developing countries from exercising this right or that dissuade them from doing so" 12.

In this sense, the G77 is definitely pointing to the effects of general trade agreements imposed by developed countries on the developing countries and used by transnational corporations to counteract national legislations that are harmful to their interests, including in health, which is also featured in the Lancet-Oslo Commission. The negative health effects can come from pressure on States to ease their technical norms and standards, a lack of instruments against abuses, and imposition of intellectual property rules, which can cause obstacles to access to medicines and other health inputs 13,14 .

\section{The United Nations post-2015 Development Agenda}

One of the principal global political processes, a component of governance that is external to the health sector, is the post-2015 Development Agenda, which is certain to influence the national States, impacting the health situation and national health systems across the world.

Leaders of the U.N. member States at Rio+20 signed the document The Future We Want 15, which provided the political basis for the future process of sustainable development and defined broad and participatory lines of work (global consultations-dialogues, High Level Panel, among others) that prepared contributions 16,17 until reaching the OWG, the peak of the entire process. This prepared the OWG Outcome Document 18 that the UNGA in 2014 considered the basis for the subsequent discussions and that was under debate until the UNGA of September 2015. In December 2014, in compliance with a UNGA determination, the Secretary-General prepared a Report 19 summarizing the contribution of the entire process, and shown in Figure 1.

The OWG proposes 17 SDGs (Figure 2), each of them containing targets (total of 169) and indicators; two of them (SDGs 16 and 17) refer to general means of implementation of the SDGs. The SDGs include Health, announced as "ensuring healthy lives and promoting wellbeing for all at all ages", which includes nine targets and four means of implementation (Figure 3). 
Figure 1

Formulation of the Agenda for the Sustainable Development Goals (SDGs) by Rio+20 and approved by the 2012 United Nations General Assembly (UNGA)

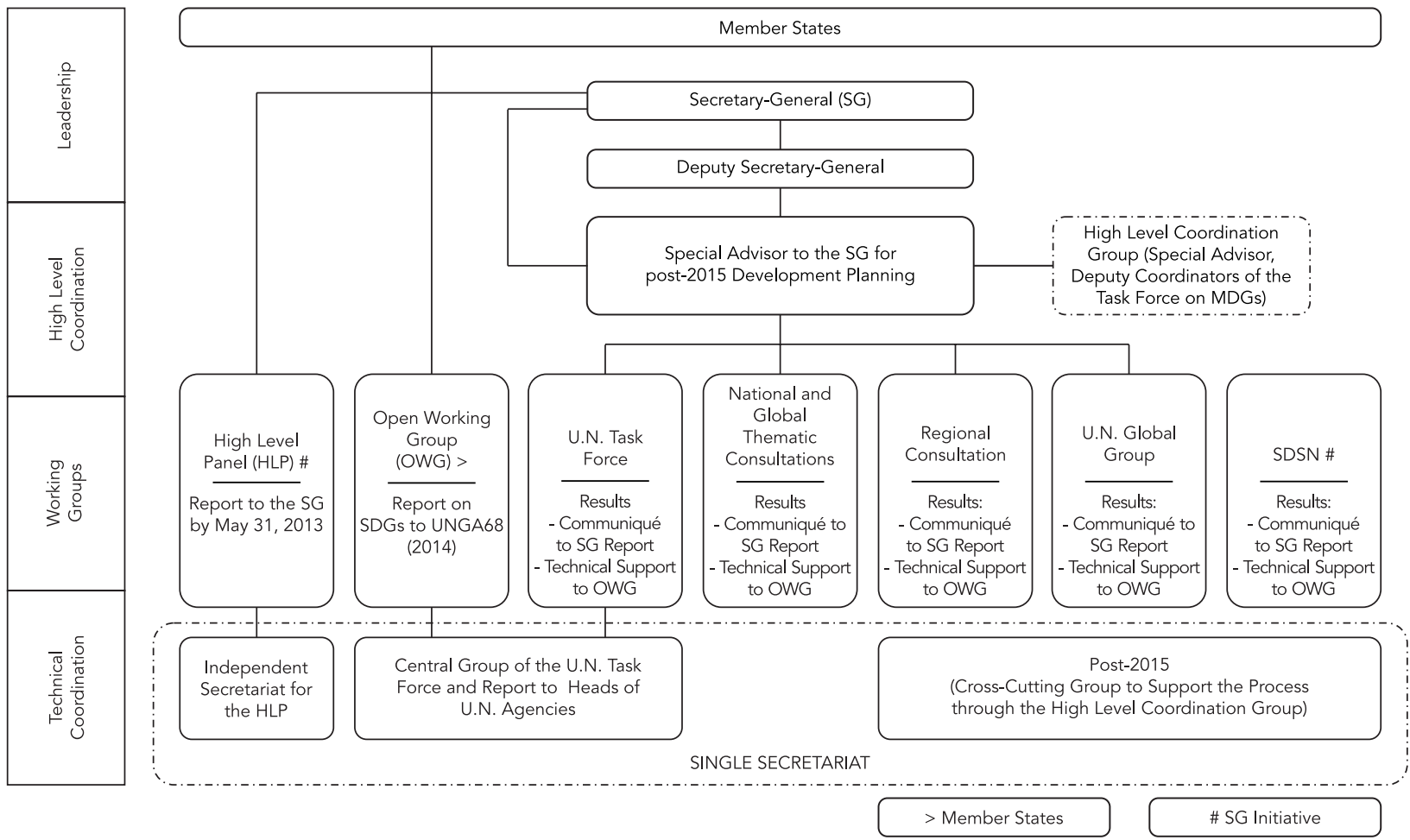

Fonte: Buss et al. 42

Three of the targets in the Health SDG refer to the MDG Agenda - targets (1), (2), and (3). The other six refer to: (4) non-communicable diseases and the promotion of mental health and wellbeing; (5) prevention and treatment of addictive substance and alcohol abuse; (6) traffic accidents; (7) sexual and reproductive health; (8) universal health coverage, including access to medicines and vaccines; and (9) environmental health. It is impossible to admit that this fractioned set of goals can achieve the greater objective of "ensuring healthy lives and promoting wellbeing for all at all ages". Likewise, the four specific means of implementation (Figure 3) do not come close to implementing the end targets ( 1 to 9 ) or much less the ambitious wording of SDG Health.

The SDG Health targets feature access to health inputs and the importance of research and development $(\mathrm{R} \& \mathrm{D})$ in relation to them (target 8 and means of implementation "c"), although the specific means of implementation or indicators have still not been laid out in detail for this case. There is no mention of innovations or "soft" technologies, essential for the development of universal, equitable, comprehensive, and highquality health systems, including in the field of public health.

Meanwhile, the position paper for Brazil's negotiations in the post-2015 Agenda 20 takes a clearer stance when it defends the following: foment scientific and technological research projects aimed at producing knowledge to achieve the universal right to health; strengthen and expand domestic industries in the production of drugs, equipment, and other health products to expand the population's access to diagnostic and therapeutic technologies, guaranteeing economy for government; and guarantee access to safe, effective, high-quality, and affordable medicines, vaccines, and other medical products, and ensure their rational prescription and dispensing. 


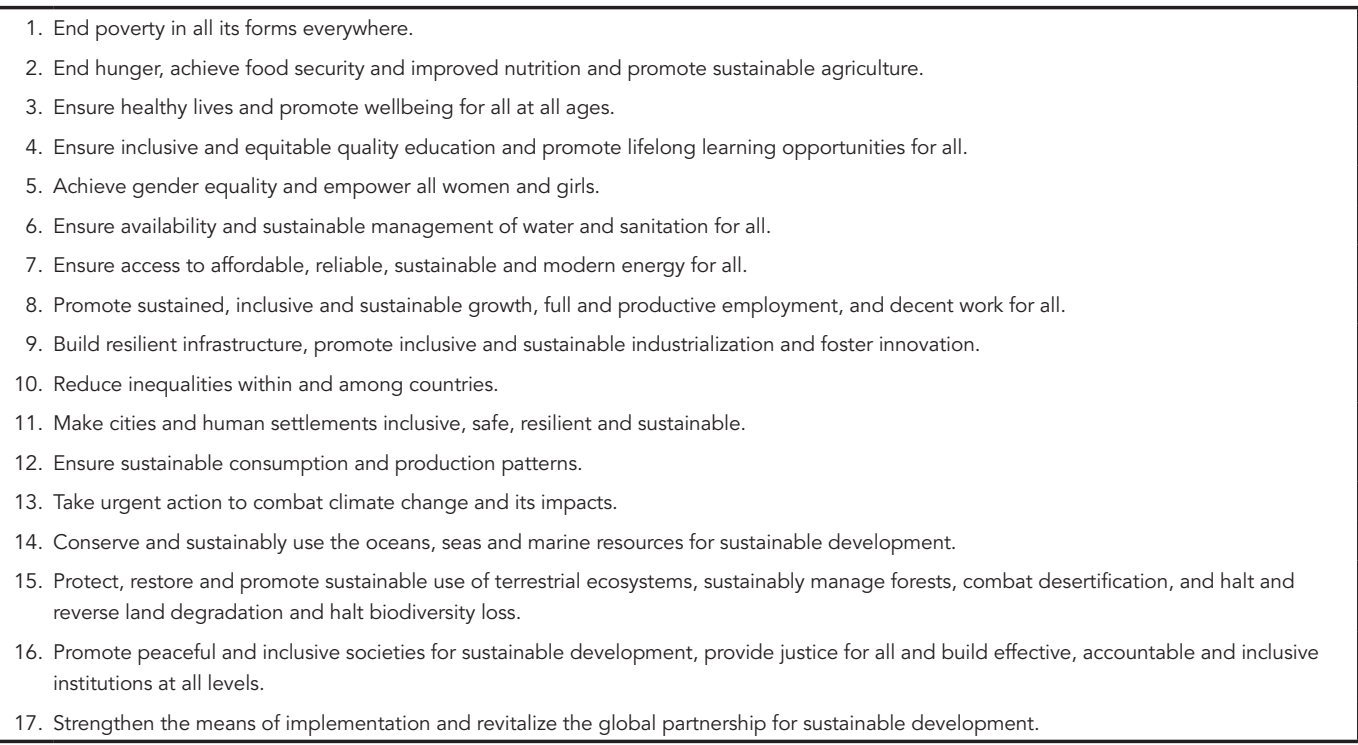

Fonte: Buss et al. ${ }^{42}$.

Given the importance of SDGs and their respective targets for health, as well as occasional gaps in them, many of the other 16 SDGs (Figure 2) contain targets that are directly related to health (for example, the elimination of hunger, food security, needs-based nutrition, reduction of malnutrition, childhood development, access to quality water and sanitation with the reduction of diseases, natural disasters and deaths, violence and health, air, soil, and water pollution and their influences on health). The Open Working Group, in a sense, thus incorporated ideas from the strategy of "health in all policies"; however, curiously enough, targets that directly mention health are absent from SDGs of an "economic nature", including sustainable industrialization or economic growth and decent employment. The protection of workers' health in potentially hazardous environments or actions on environmental pollution from production processes, for example, are ignored in SDGs 8 and 9, expressing a mismatch between economic and environmental issues and human health. It is also clear that all the SDGs are in some way "social determinants of health", even when they do no mention health directly in their targets.
There is still a long way to go to overcome the gaps, seeking to establish greater consistency and coherence among the SDGs and achieve sustainable development that truly considers and integrates its three components: social, environmental, and economic.

\section{Health and science, technology, and innovation in the post-2015 agenda}

In the field of research and innovation in health, emerging challenges require a new global impetus. These challenges include the decreasing efficacy of some medicines and other inputs, the emergence of microbial resistance, and a major change in morbidity and mortality, for example the growing prevalence of noncommunicable diseases (NCDs). Today's health inputs, many of which based on R\&D results from many decades ago, are insufficient to deal with current and future health challenges. It will be necessary to discover, develop, disseminate, and distribute new medicines, vaccines, diagnostics, and other health technologies.

Innovation can significantly improve health systems' capacity to solve these problems and 
Figure 3

Targets of the Health Sustainable Development Goals - SDGs (ensure healthy lives and promote wellbeing for all at all ages) Open Working Group of the United Nations General Assembly (OWG).

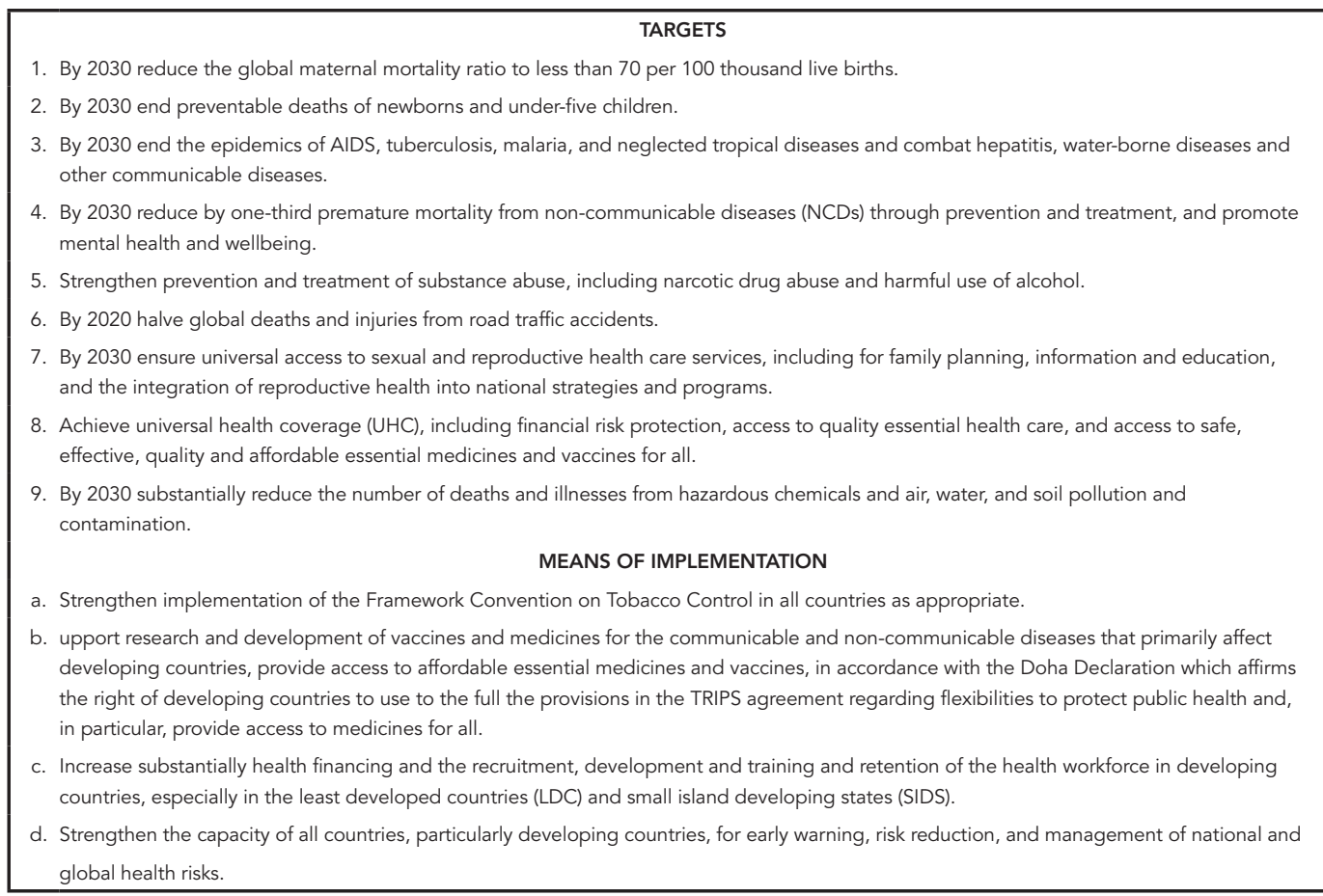

Fonte: Buss et al. 42

help contain costs, offering products at prices that are consistent with each society's reality and avoiding populations from becoming hostages to abusive practices. Persistent difficulties in access to medical technology are not natural inequalities, but serious forms of social exclusion resulting from global political and economic conditions. Innovation is relevant for developing and emerging countries, many of which are becoming innovative countries, as in the case of Brazil and its health industrial complex 21,22.

Innovation in health is the key to fighting poverty and serves as a motor force for sustainable socioeconomic development. In particular, countries that are drafting and implementing national policies for innovation in health can find opportunities in strengthening public institutions and private companies aligned with the population's needs, i.e., based on economic growth from innovations that benefit society and innovations helping decrease social inequities.
Meanwhile, receptive to the critical feeling towards the global process of knowledge production and innovation, the Secretary-General's synthesis report states, "Large amounts of public resources are allocated to military budgets, while comparatively less is spent on research and development for public goods. Public funding often subsidizes private sector research, at times leading to the public being priced out of the benefits through disadvantageous licensing and patent. This also leads to frequent subsidies of innovations that are not aligned with promoting sustainable consumption and production patterns" 20 (p. 33).

In defense of a change in the current paradigm, as the same report emphasizes, "Developing countries, and least developed country in particular, will need the support that will allow them to benefit from enhanced access to these technologies, and, ultimately, to expand domestic innovation and the development of their own technological solutions" 20 (p. 33). 
An important research and development structure in the process of the post-2015 Agenda is the Sustainable Development Solutions Network (SDSN) 23 (p. 4) launched by the U.N. Secretary-General in 2012, which "mobilizes global scientific and technological knowledge to address the challenges of sustainable development", including the design and implementation of a post-2015 global agenda for sustainable development, based on science and oriented towards action. The SDSN has stimulated the creation of national and regional networks of universities and research institutes for the development of technological solutions and educational materials for sustainable development in the country or region in which it is located. The most recent contribution of the SDSN was the development of indicators for each of the SDGs and a model for monitoring them 24 .

Much needs to be done in 2015 for the U.N. Development Agenda to actually represent a coherent international political pact and not only a set of good intentions, or declarations that merely cover up the true causes of the prevailing unsustainable process.

\section{Global health governance}

The role of the World Health Organization (WHO) in global health governance since the Organization's foundation in 1948 has received frequent criticisms that led to a process of reform in the Organization 25, still not finalized, and with limited reach given health's current complexity for national and global social policies.

Nongovernmental organizations, private foundations, other United Nations agencies, and large transnational corporations have occupied growing spaces in global policies. The transnational pharmaceutical companies, for example, do global business on the order of some 6.5 trillion dollars, encompassing the pharmaceuticals market and research, development, and innovation in health. As a result, many decisions with significant impacts on the population's health are no longer made by national governments or international organizations, but in global corporate board rooms. This imbalance between the public and private sectors requires a critical debate to ensure health and wellbeing as a global public good.

Due to the lack of global and national regulation, expenditures on medicines account for an important major share of health costs in developing countries, which are heavily dependent on the availability of medicines at affordable prices. In the pharmaceutical sectors, according to the industry, $R \& D$ costs are extremely high, leading companies to invest only in drugs with the potential for high profits, the reason they claim for reduced investments in $\mathrm{R} \& \mathrm{D}$ for the diseases that affect the world's poorest populations.

\section{Health and ST\&I in the WHO: health inputsin the sphere of global health governance}

The increasing economic deterioration and general aggravation in social inequalities, identified clearly by experts like Stiglitz 26 and Piketty 27 , are known to impact local and global health systems. For developing countries, the crisis poses new obstacles to the formulation, implementation, and consolidation of public health policies for universal and equitable access. Difficulties in the supply of essential medicines and persistent technological weaknesses are some of the principal issues that surface in debates in the World Health Assemblies. Thousands of people in developing countries are deprived daily of therapeutic resources already approved on the basis of their efficacy, quality, and safety. In addition, the chronic shortage of investment prevents the development of solutions to diseases that particularly affect the poorest countries.

A top priority for global health should be to ensure access by populations in developing countries to health products at non-abusive prices. This problem is not new; access to products and technologies has been debated for decades. The advent of the TRIPS Agreement 28 in 1994 and its subsequent internalization by patent laws in all the member countries of the World Trade Organization (WTO) brought a set of new issues resulting from the monopolistic effects of the mandatory protection of pharmaceutical inventions. By promoting the absence of competition for a reasonable period of time (20 years on average), the prices of new medicines present a steady and worrisome increase, deepening the prospects of exclusion for already vulnerable populations. The result is huge disparities in life expectancy between developed and developing countries. The benefits that technological progress can provide are still not for everyone.

At the international level, the discussion on access and health goods has accelerated and has important antecedents. In 1990, a report by the Commission for Health Research for Development 29 , an independent international initiative, explained a series of questions related to the shortage of needs-based research in less favored nations. It also addressed research priorities and the relevance of capacity-building. 
In 2000, the Global Forum for Health Research 30 coined the expression "10/90 gap", now imprecise, but still used in various forums. According to the main concept, less than $10 \%$ of health research spending is allocated for diseases or conditions that account for $90 \%$ of the global burden of diseases.

In 2001, the Commission on Macroeconomics and Health 1 , created by the WHO, concluded that health is an indispensable prerequisite for development. Citing the MDGs, the report states that the challenge is feasible, but achieving it is not an automatic process. Political efforts and sustainable flows of resources are indispensable. Thus, there can be no welfare state without on-going investments to foster the generation and diffusion of technological knowledge in health, aimed at reducing poverty. The Commission innovated by proposing three categories of diseases: type I diseases, which affect both rich and poor countries, especially including non-communicable diseases; type II diseases, affecting both groups of countries, but with a predominant presence in poor countries, with tuberculosis as an example; and type III diseases, typical of developing countries, like Chagas disease and leishmaniasis. The categorization is an initiative to signal discrepancies between the efforts made for each group of diseases and their socioeconomic context. Another relevant classification was proposed by Doctors Without Borders, dividing diseases into global, neglected, and more neglected 31 .

In addition to financing and adequate prioritysetting for research, the relations between health and trade, especially intellectual property rights, invaded academic circles, civil society debate, and the agenda of international organizations. In the late 1990s, tensions already ran high between the developed countries, multinational corporations, and the developing countries. The initial adoption of TRIPS raised numerous questions: How could strengthening intellectual property rights contribute to development? How to deal with the priority focus on high-profit products and rising prices and make treatment feasible with antiretroviral medicines and others for historically neglected populations? Would it be possible to promote fair trade in generics and incentivize local production? In this context, it is worthwhile to recall the legal case filed by 39 multinational pharmaceutical companies against the government of South Africa in 1998, based on a legal provision dealing with the implementation of one of the flexibilities in the TRIPS Agreement, aimed at facilitating access to medicines for HIV/AIDS at affordable prices. In 2001, the claim was withdrawn after strong reaction by civil society, human rights groups, and the developing countries.
The most emblematic reaction to this fact was definitely the approval of the Doha Declaration on the TRIPS Agreement and Public Health 32, in 2001. The Declaration clarifies a fundamental point: countries are free to make use of any flexibilities in the Agreement, without suffering retaliation as a result. The instrument alleviated the constant threats of proceedings and panels.

One of the most interesting and relevant cases began after the ruling by the World Health Assembly of 2003 33, authorizing the creation of a special ad hoc committee to investigate the issue and the flaws in the system of incentives. In 2006, the group produced a report 34 (p. 187) containing 60 recommendations. According to one recommendation, "WHO should develop a Global Plan of action to secure enhanced and sustainable funding for developing and making accessible products to address diseases that disproportionately affect developing countries".

Next, in 2006, the Intergovernmental Working Group on Public Health, Innovation, and Intellectual Property (IGWG) 35 was formed, culminating in the proposal passed by the World Health Assembly in 2008, the Global Strategy and Plan of Action on Public Health, Innovation, and Intellectual Property (Resolution WHA61.21) 36. With the Strategy officially adopted on the WHO agenda, one of the fundamental points gained priority. How to guarantee the necessary flow of investments to ensure the generation of relevant innovations for the countries of the South? How to coordinate research resources and priorities? The underproduction of global public goods, the problem of incentives, and the need to correct market flaws led to the debate's continuity.

In 2010, the issues of incentives and coordination were expressed in the report by the Expert Working Group on Research and Development: Coordination and Financing (EWG) 37. However, despite the advances achieved in the Assembly, the countries requested the continuity of the investigations, and the Consultative Expert Working Group on Research and Development: Financing and Coordination (CEWG) 37 was created. The Commission's mandate included two elements from Resolution WHA61.21 - element 2 - the promotion of research and development; and element 7 - the promotion of mechanisms for sustainable financing. The focus was on the problems of financial resources and coordination of research and development activities for health products related to type II and III diseases and type I diseases with regard to the specific needs of developing countries.

The CEWG report highlighted the need for more constant and efficient public funding and innovative mechanisms for other financial 
contributions, to coordinate global efforts in research and development (R\&D), and to found an observatory for global R\&D activities in health.

The spinoffs of the work by the CEWG focused mainly on the inauguration of the Global Observatory for Health Research and Development 39 and the choice and implementation of the demonstration projects currently under way. Through public calls for projects, the six regional offices of the WHO system sent 22 projects that were screened in a selection process by a group of experts. Of these, eight projects were identified as promising. Next, analyses were performed as to adherence to the underlying principles of the CEWG report (delinkage, open knowledge innovation, licensing for access, financing mechanisms, coordination mechanisms, capacity-building). Based on the information provided by the proponents and the independent external evaluators in relation to the scientific merit and adherence to the CEWG principles, the World Health Assembly of 2014 launched the implementation of the first four demonstration projects 40 . At the 2015 World Health Assembly, two of the four remaining proposals were selected ${ }^{41}$.

Implementation of the demonstration projects aims to explore new ways of generating and managing innovation in the health field, testing elements that may contribute to innovative financing and the expansion of the reserve of global public goods. Price impact is an equally important focus. For example, application of the delinkage principle aims to delink R\&D costs from the product's final price. The proposed system is not a replacement for the prevailing incentives model, mainly via patent protection. It is a complementary and collaborative model that aims to a favor millions of people with novel medicines, vaccines, and diagnostics at more affordable prices.

These are crucial initiatives for improving global policy in the field of research, development, and innovation in health. They are crucial yet insufficient, since the scope of the Global Strategy and Plan of Action is much broader and more challenging, requiring member countries to abandon worn-out paradigms and adopt more daring approaches to build new futures, includ- ing stakeholders that have historically been ignored or underserved.

The measures in the Global Strategy need to be integrated and well-linked to other programs, policies, and initiatives such as Social Determinants of Health, the post-2015 Development Agenda, and the WHO reform, in search of responsible development allied with social justice.

\section{Conclusions}

Innovation in health is undeniably important in the economic and social dimensions. Innovation is essential for the development of a health industrial complex that responds to the population's health needs. It is part of both the United Nations post-2015 development agendas at the global level and the national development agendas.

Innovation's presence in the United Nations post-2015 Agenda discussions is still incipient, although taken for granted when mentioning research and development and access to "essential" medicines and vaccines, a concept permeating all the debates. Still, an alternative approach would be the concept of "necessary" inputs, corresponding better to a given population's epidemiological needs.

In the WHO, R\&D and innovation, as well as access to health inputs, have received growing attention and have been the object of controversy, at least in the last 15 years. The high price of medicines and other inputs and the low access to new products led to the creation of successive working groups seeking to harmonize the conflicting interests of developed and developing countries and representatives of corporations and nongovernmental organizations representing civil society, in an extremely slow debate given the size and urgency of global needs.

Both major processes, innovation in health and access to its results, need to be streamlined, but this requires democratization of participation by the greatest stakeholders, namely patients and the general population in the poorest countries, as the only way to overcome the "zero sum" game prevailing thus far in the debates among representatives of the member States. 


\section{Contributors}

P. M. Buss, C. Chamas, M. Faid and C. Morel participated in all stages of the article's elaboration.

\section{Acknowledgments}

The authors wish to thank the Brazilian National Institute of Science and Technology for Innovation in Neglected Diseases (INCT-IDN) (CNPq-SCTIE/MSFAPERJ) for the financial support.

\section{References}

1. World Health Organization. Macroeconomics and health: investing in health for economic development. Report of the Commission on Macroeconomics and Health. Geneva: World Health Organization; 2001

2. Commission on Social Determinants of Health. Closing the gap in a generation: health equity through action on the social determinants of health. Final report of the Commission on Social Determinants of Health. Geneva: World Health Organization; 2008.

3. Gadelha CAG, Costa LS. Saúde e desenvolvimento no Brasil: avanços e desafios. Rev Saúde Pública 2012; 46 Suppl:13-20.

4. Department of Economic and Social Affairs, United Nations. United Nations Development Agenda: development for all. New York: United Nations; 2007.

5. Buss PM. The 2006 Hugh Rodman Leavell lecture "globalization, poverty, and health". J Public Health Policy 2007; 28:2-25.

6. United Nations. Resolution A/RES/55/2. http:// www.un.org/millennium/declaration/ares552e. pdf (accessed on 23/Jan/2006).

7. Organização Mundial da Saúde. Declaração política do Rio sobre determinantes sociais da saúde. http://www.who.int/sdhconference/declaration/ Rio_political_declaration_portuguese.pdf (accessed on 23/Jan/2016).

8. World Health Organization. Moscow Declaration: preamble. http://www.un.org/en/ga/presi dent/65/issues/moscow_declaration_en.pdf (accessed on 23/Jan/2016).

9. Amorim C, Douste-Blazy P, Wirayuda H, Støre JG, Gadio CT, Dlamini-Zuma N, Pibulsonggram N. Oslo Ministerial Declaration. Global health: a pressing foreign policy issue of our time. Lancet 2007; 369:1373-8.
10. Canfin P. Eide EB, Natalegawa M, Ndiaye M, Nkoana-Mashabane $\mathrm{M}$, Patriota A. Our common vision for the positioning and role of health to advance the UN development agenda beyond 2015. Lancet 2013; 381:1885-6.

11. Ottersen OP, Dasgupta J, Blouin C, Buss P, Chongsuvivatwong V, Frenk J, et al. As origens políticas das inequidades em saúde: perspectivas de mudança http://ecos-crisfiocruz.bvs.br/tikidownload_file.php?fileId=222 (accessed on 24/ Jan/2016).

12. Grupo de los 77. Por un nuevo orden mundial para vivir bien. http://www.g77bolivia.com/es/declara cion-de-santa-cruz (accessed on 24/Jan/2016).

13. Wallach LM. Dez ameaças aos norte-americanos... Grande Mercado Transatlântico: Dez ameaças aos norte-americanos... e dez ameaças aos europeus. Le Monde Diplomatique Brasil 2014; (84):12.

14. Jäcklein W. ...e dez ameaças aos europeus. Le Monde Diplomatique Brasil 2014; (84):13.

15. United Nations. Resolution A/RES/66/288. http:// www.un.org/ga/search/view_doc.asp?symbol=A/ RES/66/288\&Lang (accessed on 24/Jan/2016).

16. Task Team. Health in the post-2015 agenda. Report of the Global Thematic Consultation on Health. http://www.worldwewant2015.org/file/337378/ download/366802 (accessed on 20/Jul/2014).

17. United Nations. A new global partnership: eradicate poverty and transform economies through sustainable development. New York: United Nations; 2013.

18. United Nations. Open working group on sustainable development goals. http://sustainabledevel opment.un.org/focussdgs.html (accessed on 24/ Jan/2016). 
19. United Nations. The road to dignity by 2030: ending poverty, transforming all lives and protecting the planet. http://www.un.org/disabilities/docu ments/reports/SG_Synthesis_Report_Road_to_ Dignity_by_2030.pdf (accessed on 23/Jan/2016).

20. Ministério das Relações Exteriores. Negociações da Agenda de Desenvolvimento pós-2015: elementos orientadores da posição brasileira. Brasília: Ministério das Relações Exteriores; 2014.

21. Morel CM, Acharya T, Broun D, Dangi A, Elias C, Ganguly NK, et al. Health Innovation networks to help developing countries address neglected diseases. Science 2005; 309:401-4.

22. Gadelha CAG, Maldonado JMSV, Costa LS. Complexo industrial da saúde: dinâmica de inovação no âmbito da saúde. In: Giovanella L, Escorel S, Lobato LVC, Noronha JC, Carvalho AI, organizadores. Políticas e sistemas de saúde no Brasil. Rio de Janeiro: Editora Fiocruz, 2012. p. 209-37.

23. Thematic Group on Health for All of the Sustainable Development Solutions Network. Health in the framework of sustainable development. Technical Report for the Post-2015 Development Agenda. New York, United Nations; 2014.

24. Sustainable Development Solutions Network. Indicators and a monitoring framework for sustainable development goals: launching a data revolution for the SDGs. New York: United Nations; 2015.

25. World Health Organization. WHO reform. http:// www.who.int/about/who_reform/en/ (accessed on 23/Jan/2016).

26. Stiglitz J Economic stagnation by design. http:// www.social-europe.eu/2014/02/economic-stag nation/ (accessed on 23/Jan/2016).

27. Piketty T. O capital no século XXI. Rio de Janeiro: Intrínseca; 2014.

28. World Trade Organization. Agreement on traderelated aspects of intellectual property rights. Geneva: Word Trade Organization; 1995.

29. Commission on Health Research for Development. Health research: essential link to equity in development. New York: Oxford University Press; 1990.

30. Global Forum for Health Research. The 10/90 report on health research 1999. Geneva: Global Forum for Health Research; 1999.

31. Médecins Sans Frontières. Fatal imbalance: the crisis in research and development for drugs for neglected diseases. Geneva: Médecins Sans Frontières; 2001.

32. World Trade Organization. WTO Declaration on the TRIPS Agreement and public health. http:// www.wto.org/English/thewto_e/minist_e/min 01_e/mindecl_trips_e.pdf (accessed on 24/Jan/ 2016).
33. World Health Assembly. Resolution WHA56.27. Intellectual property rights, innovation and pub lic health. apps.who.int/gb/archive/pdf_files/ WHA56/ea56r27.pdf (accessed on 24/Jan/2016).

34. World Health Organization. Public health, innovation and intellectual property rights. Report of the Commission on Intellectual Property Rights, Innovation and Public Health. Geneva: World Health Organization; 2006.

35. World Health Organization. Intergovernmental working group on public health, innovation and intellectual property (IGWG). http://www.who. int/phi/igwg/en/ (accessed on 03/Feb/2015).

36. World Health Organization. Global strategy and plan of action on public health, innovation and intellectual property. Geneva: World Health Organization; 2011.

37. World Health Organization. Report of the World Health Organization Expert Working Group on Research and Development Financing. Geneva: World Health Organization; 2010.

38. World Health Organization. Research and development to meet health needs in developing countries: strengthening global financing and coordination. Report of the Consultative Expert Working Group on Research and Development. Geneva: World Health Organization; 2012.

39. Terry RF, Salm Jr. JF, Nannei C, Dye C. Creating a global observatory for health R\&D. Science 2014; 345:1302-4.

40. World Health Assembly. Resolution WHA67.15. Strengthening the role of the health system in addressing violence, in particular against women and girls, and against children. apps.who.int/gb/ ebwha/pdf_files/WHA67/A67_R15-en.pdf (accessed on 24/Jan/2016).

41. World Health Assembly. A68/34 Add.1 Follow-up of the report of the Consultative Expert Working Group on Research and Development: financing and coordination. Health research and development demonstration projects. apps.who.int/gb/ ebwha/pdf_files/WHA68/A68_34Add1-en.pdf (accessed on 24/Jan/2016).

42. Buss PM, Magalhães DP, Setti AFF, Gallo E, Franco Netto FA, Machado JMH, et al. Saúde na Agenda de Desenvolvimento pós-2015 das Nações Unidas. Cad Saúde Pública 2014; 30:2555-70. 


\section{Resumo}

O objetivo central deste texto é discutir desenvolvimento e saúde sob a ótica da influência da governança da saúde global, utilizando como traçador a dimensão das políticas de pesquisa, desenvolvimento e inovação em saúde, que se referem, de um lado, a insumos importantes para o sistema de saúde - como fármacos e medicamentos, vacinas, reativos para diagnóstico e equipamentos e, de outro, a conceitos e práticas inovadoras para o aperfeiçoamento dos sistemas de saúde e da saúde pública. Examina os dois principais macroprocessos que influenciam o desenvolvimento e a saúde: a Agenda do Desenvolvimento para o pós-2015 e o processo sobre pesquisa e desenvolvimento, propriedade intelectual e acesso a insumos em saúde em curso na Organização Mundial da Saúde. Conclui que muito há que ser feito para que a referida Agenda possa representar um pacto político internacional coerente e viável, e que os dois macroprocessos relacionados com a inovação em saúde precisam ser agilizados, mas para isto torna-se necessária a democratização da participação dos maiores interessados - os pacientes e, de modo geral, a população dos países mais pobres - pois só desta maneira será superada a "soma zero" em que se encontra o embate entre os representantes de Estados-membros nos debates atuais.

Pesquisa; Desenvolvimento Sustentável; Inovação

\section{Resumen}

El objetivo central de este texto es discutir el desarrollo y la salud, desde la óptica de la influencia de la gobernanza de la salud global, utilizando como eje vertebrador la dimensión de las políticas de investigación, desarrollo e innovación en salud, que se refieren, por un lado, a insumos importantes para el sistema de salud -como fármacos y medicamentos, vacunas, reactivos para diagnóstico y equipamientos y, por otro a conceptos y prácticas innovadoras, para el perfeccionamiento de los sistemas de salud y de la salud pública. Se examinan los dos principales macroprocesos que influencian el desarrollo y la salud: la Agenda del Desarrollo para el pos-2015 y el proceso sobre pesquisa $y$ desarrollo, propiedad intelectual y acceso a insumos en salud, en curso dentro de la Organización Mundial de la Salud. Se concluye que se deben realizar muchos esfuerzos para que la referida agenda pueda representar un pacto político internacional coherente y viable, asimismo, los dos macroprocesos relacionados con la innovación en salud necesitan agilizarse, pero para esto es necesaria la democratización de la participación de los mayores interesados: los pacientes y, de manera general, la población de los países más pobres, pues sólo de esta forma será superada la "suma cero" donde se encuentra el embate entre los representantes de estados miembros en los debates actuales.

Investigación; Desarrollo Sostenible; Innovación
Submitted on 24/Mar/2015

Final version resubmitted on 10/Mar/2016 Approved on 16/Mar/2016 